\title{
The Amino Acid Substitution and Some Chemical Properties of a Variant Human Erythrocyte Carbonic Anhydrase: Carbonic Anhydrase $\mathbf{I d}_{\text {Michigan }}{ }^{1}$
}

\author{
Thomas B. Shows ${ }^{2}$
}

Received 3 July 1967

Carbonic anhydrase $I d_{\text {Michigan, }}$ an electrophoretic variant of human red cell carbonic anhydrase $I$, was purified from erythrocytes obtained from an individual heterozygous for the trait. Primary structural analysis indicates that a lysine residue has exchanged for a threonine residue in the variant enzyme. After isolation, there was approximately 1.8 times as much normal as variant enzyme. Thermostability studies demonstrated that carbonic anhydrase Id was more thermolabile than the normal enzyme. The normal and variant enzymes showed no differences in specific carboxylesterase activity or $\mathrm{CO}_{2}$ hydratase activity. Utilizing the carboxylesterase activity toward $\beta$-naphthyl acetate, the normal and variant enzymes had similar Michaelis constants, $\mathrm{pH}$ profiles, and rates of inhibition by acetazolamide. Immunochemical studies did not demonstrate an antigenic difference for the variant enzyme.

\section{INTRODUCTION}

Carbonic anhydrase isolated from human erythrocytes consists of two distinct molecular forms which have been designated carbonic anhydrase I (CA I) and carbonic anhydrase II (CA II) (cf. Tashian, 1965); they have also been termed B and C, respectively (Rickli et al., 1964; Nyman and Lindskog, 1964; and Armstrong et al., 1966). Both forms have a molecular weight of about 30,000 , have similar general

Supported in part by Research Grants 2 T1 GM-76, 5 TO1 GM 00071-09, and GM 09252 from U.S. Public Health Service.

${ }^{1}$ This report is a portion of a dissertation submitted to the University of Michigan in partial fulfillment of the requirements for the doctor of philosophy degree.

2 Department of Human Genetics, University of Michigan Medical School, Ann Arbor, Michigan. Present address: Department of Biology, Yale University, New Haven, Connecticut. Reprint requests should be sent to Dept. of Human Genetics, University of Michigan Medical School, Ann Arbor, Michigan. 
catalytic activities, and consist of single polypeptide chains with one zinc atom and one cysteine residue per enzyme molecule; the two molecular forms differ, however, in relative amounts synthesized and a number of physicochemical properties such as isoelectric points, amino acid composition, specific activities, and antigenicity (cf. Rickli et al., 1964; Malmström et al., 1964; Edsall et al., 1966; and Micheli and Buzzi, 1964).

In man, no genetic variants of CA II have been found, but four rare genetically determined electrophoretic variants of human red cell CA I have been described (Tashian, 1965; Tashian et al., in press). Studies on the characterization of one of these mutant forms, carbonic anhydrase $\mathrm{Id}_{\text {Michigan }}$ (CA Id), which was discovered in an American Negro family residing in Michigan (Tashian, 1965), is reported here. This investigation describes the amino acid substitution in CA Id and compares some kinetic and immunochemical properties of CA Id and the normal (CA Ia) enzyme.

The proposita is a 79-year-old hospitalized mental patient who has had three pregnancies; the first resulted in a daughter with the CA Id trait from a first marriage while two terminated as miscarriages from a second marriage. Blood was obtained from the proposita's heterozygous 59-year-old daughter who has had three miscarriages and no living children. The only other living relative of the proposita is a brother who was not available for study.

\section{MATERIALS AND METHODS}

Four half-pints of blood were obtained from the proposita's daughter who is heterozygous for the variant enzyme. Whole blood was drawn into acid-citrate-dextrose (ACD) at a final concentration of $13 \%$ and refrigerated at $3 \mathrm{C}$ until the isolation of the enzymes was begun on the following day. Normal erythrocytes, collected in either heparin or ACD, were obtained from the University of Michigan Blood Bank.

\section{Isolation of Carbonic Anhydrase Ia, Id, and II}

From a half pint of whole blood, $100-125 \mathrm{ml}$ of packed red cells were obtained. The cells were washed, hemolyzed, and the enzymes isolated essentially as described by Tashian et al. (1966) unless stated otherwise. The purification was initiated by a chloroform-ethanol extraction (Fraction I). A second extraction, yielding about $5 \%$ of the protein contained in the first, was performed but not combined with Fraction I. Fraction I was then applied to a DEAE-cellulose column $1 \mathrm{~cm}$ in diameter; the height depended on the amount of protein in the sample $(1 \mathrm{~g}$ DEAE-cellulose per $100 \mathrm{mg}$ of protein). The carbonic anhydrases all passed through the column as a single peak (Fraction II). Preparative starch gel electrophoresis of Fraction $\amalg$ yielded purified CA Ia, CA Id, and CA II which are designated Fraction III A, III B, and III C, respectively. These fractions were dialyzed $24 \mathrm{hr}$ against $1.0 \mathrm{~mm}$ tris- $\mathrm{HCl}, p \mathrm{H} 7.5$. Figure 1 shows the starch gel electrophoretic pattern of the proteins after each isolation step. Table I illustrates the purification results.

After isolation, stock enzyme solutions were prepared at a concentration of $5-10 \mathrm{mg}$ per milliliter of $1.0 \mathrm{mM}$ tris- $\mathrm{HCl}, p \mathrm{H}$ 7.5. Some samples for structural studies 


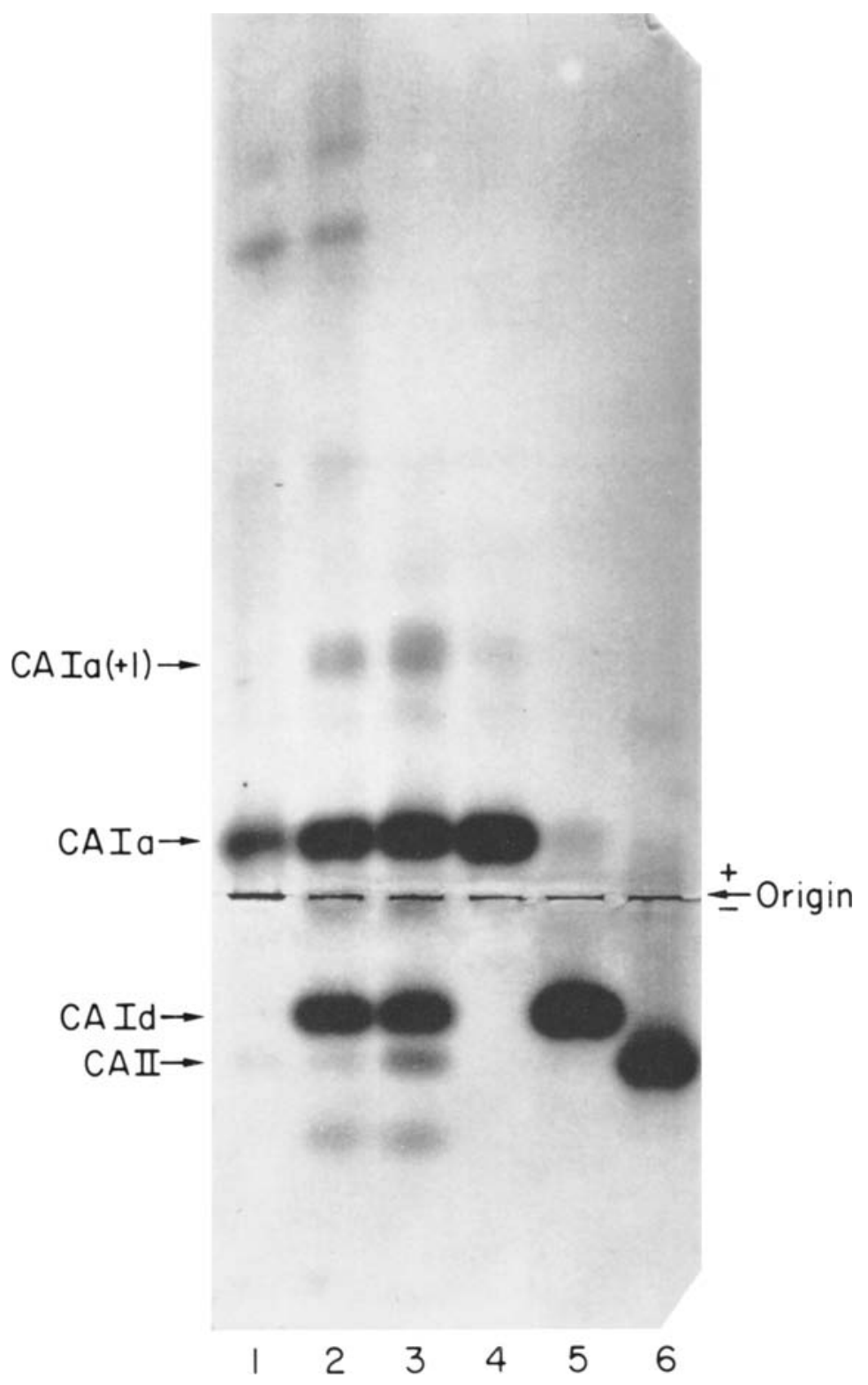

Fig. 1. Starch gel electrophoretic pattern of the proteins after each isolation step. 1 and 2 , chloroform-ethanol extracts of normal and variant hemolysates, respectively; 3 , variant DEAE effluent; 4, 5, and 6 contain, respectively, CA Ia, CA Id, and CA II after preparative electrophoresis. Each sample contained $1.5 \mathrm{mg}$ of protein except sample 1 which contained $1.0 \mathrm{mg}$. Vertical electrophoresis was carried out for $18-20 \mathrm{hr}$ and $6 \mathrm{v} / \mathrm{cm}$ in $0.02 \mathrm{M}$ borate$\mathrm{NaOH}$ gel buffer, $p \mathrm{H} 8.8$, and $0.3 \mathrm{M}$ borate- $\mathrm{NaOH}$ bridge buffer, $p \mathrm{H} 8.0$, containing $0.02 \mathrm{M} \mathrm{NaCl}$ (Tashian and Shaw, 1962). Protein was detected by staining with nigrosin. CA Ia $(+1)$ is a minor component of CA Ia and is discussed with regard to Fig. 2 . The protein bands cathodal to CA II in 2 and 3 may be minor components of CA II. A lower protein concentration accounts for their absence in 1 . 

were stored at $-25 \mathrm{C}$. CA Ia and CA Id did not lose noticeable specific carboxylesterase activity when frozen and thawed. Freshly isolated preparations of CA Ia and CA Id were employed for the kinetic studies. These solutions were not frozen but kept at 2-3 C. When stored in this fashion, the enzymes maintained essentially the same specific carboxylesterase activity for periods up to 3 months.

Protein was assayed by a modification of the method of Lowry et al. (1951).

Table I. Purification of Carbonic Anhydrase Ia, Id, and II from Normal and Variant Erythrocytes

\begin{tabular}{|c|c|c|c|c|c|c|c|c|c|c|}
\hline \multirow[t]{2}{*}{ Fractio } & ion & \multirow[t]{2}{*}{ Step } & \multicolumn{2}{|c|}{$\begin{array}{l}\text { Protein }^{a} \\
\text { (mg) }\end{array}$} & \multicolumn{2}{|c|}{$\begin{array}{l}\text { Yield of } \\
\text { protein } \\
(\%)\end{array}$} & \multicolumn{2}{|c|}{$\begin{array}{c}\text { Carboxylesterase } \\
\text { activity } \\
\text { (units } / \mathrm{mg} \text { ) }\end{array}$} & \multicolumn{2}{|c|}{$\begin{array}{c}\mathrm{CO}_{2} \text { hydratase } \\
\text { activity } \\
\text { (units } / \mathrm{mg} \text { ) }\end{array}$} \\
\hline & & & Normal & Variant & Normal & Variant & Normal & Variant & Normal & Variant \\
\hline I & \multicolumn{2}{|c|}{ Chlorof } & 4.0 & 3.7 & 100 & 100 & 0.027 & 0.028 & 7.60 & 7.47 \\
\hline II & \multicolumn{2}{|c|}{ DEAE-cellulose } & 3.5 & 3.5 & 88.0 & 94.5 & 0.034 & 0.033 & 8.50 & 8.80 \\
\hline \multirow[t]{4}{*}{ III } & \multicolumn{10}{|c|}{$\begin{array}{l}\text { Preparative } \\
\text { electrophoresis }\end{array}$} \\
\hline & & CA Ia & 1.77 & $1.19^{d}$ & 45.0 & 32.2 & 0.038 & 0.037 & 7.06 & 7.60 \\
\hline & B & CA Id & & $0.65^{d}$ & & 17.6 & & 0.036 & & 6.57 \\
\hline & $\mathrm{C}$ & CA II & 0.07 & 0.06 & 0.18 & 1.6 & 0.033 & 0.032 & 21.67 & 22.67 \\
\hline
\end{tabular}

${ }^{a}$ From $1 \mathrm{ml}$ of packed erythrocytes.

${ }^{b} 1$ Unit $=\mu$ moles $\beta$-naphthol formed per minute.

$c \Delta$ O.D. at $276 \mathrm{~m} \mu / \mathrm{sec}$.

Ratio of mutant to normal enzyme in variant cells is $0.55: 1$.

Sodium citrate was used in Reagent B instead of sodium tartrate to give a more stable reagent (Eggstein and Kruetz, 1955).

\section{Enzyme Assays}

The assay systems utilize the ability of the enzyme to hydrolyze certain carboxylic esters in addition to the conventional hydration of $\mathrm{CO}_{2}$. The activity of carbonic anhydrase toward $\beta$-naphthyl acetate and $p$-nitrophenyl acetate was measured as described by Tashian et al. (1966). Esterase activities were determined by measuring $\beta$-naphthol liberation from $\beta$-naphthyl acetate and $p$-nitrophenol liberation from $p$-nitrophenyl acetate. The $\mathrm{CO}_{2}$ hydratase activity of the enzymes was measured by Nyman's method (Nyman, 1963) using modifications described by Tashian et al. (1966). The method utilizes the change in ultraviolet absorption from the basic to the acidic form of the Veronal buffer.

\section{Peptide Analysis}

Peptide mapping techniques were essentially those described by Tashian et al. (1966) as modified from Katz et al. (1959) and Chernoff and Liu (1961). The enzymes were denatured by heating at $95 \mathrm{C}$ for $3 \mathrm{~min}$ in $0.2 \mathrm{M}$ ammonium carbonate buffer, $p \mathrm{H} 8.5$, at a concentration of about $5 \mathrm{mg}$ protein to $1 \mathrm{ml}$ buffer. After washing the denatured protein twice with $6-8 \mathrm{ml}$ of the same buffer, the precipitate was suspended in the ammonium carbonate buffer at a concentration of $20 \mathrm{mg}$ protein per milliliter of buffer and digested with either of three proteolytic enzymes. 
Chymotrypsin (3X crystallized, Worthington Biochemicals Corp.) was added to the denatured protein in a ratio of 1:100 and digested for $3 \mathrm{hr}$ at $37 \mathrm{C}$. The digest was then centrifuged at $3000 \mathrm{rpm}$ for $15 \mathrm{~min}$ to separate the undigested chymotryptic "core."

The denatured protein was also digested with $2 \%$ (by weight) trypsin (2X crystallized, Worthington) for $90 \mathrm{~min}$ under the above conditions. After digestion and centrifugation, the undigested tryptic core was washed twice with the ammonium carbonate buffer, suspended at the same concentration of $20 \mathrm{mg}$ protein to $1 \mathrm{ml}$ buffer, and digested with $1 \%$ chymotrypsin for $3 \mathrm{hr}$. This same procedure for handling cores was followed when the chymotryptic core, obtained after chymotryptic digestion of the denatured protein, was digested with $2 \%$ trypsin for $90 \mathrm{~min}$.

Two milligrams of the washed denatured protein was digested with pepsin after the ammonium carbonate buffer was removed by evaporation to dryness in an evacuated desiccator over $\mathrm{KOH}$ pellets and phosphorus pentoxide. The residue was dissolved in $0.7 \mathrm{ml}$ of $0.01 \mathrm{~N} \mathrm{HCl}$ and $2 \%$ (by weight) pepsin ( $2 \mathrm{X}$ crystallized, Worthington) was added initially and after $4 \mathrm{hr} 1 \%$ was added. Pepsin was prepared as a $1 \mathrm{mg}$ per milliliter $0.01 \mathrm{~N} \mathrm{HCl}$ solution. Hydrolysis was performed at $40 \mathrm{C}$ for $20 \mathrm{hr}$. A very small core remained after centrifugation.

Two to three milligrams of the chymotryptic, tryptic, or peptic digests were applied to each sheet of chromatography paper (Whatman 3MM) and descending chromatography in $n$-butanol-pyridine-acetic acid-water $(15: 10: 3: 12)$ was carried out for $21 \mathrm{hr}$ at room temperature. Electrophoresis was performed in pyridine-acetic

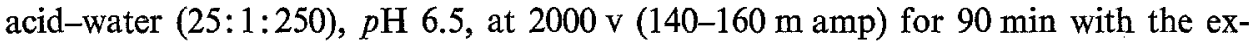
ception that pepsin digests were subjected to electrophoresis for $2 \mathrm{hr}$. The sheets were dried and sprayed lightly with $0.025 \%$ ninhydrin in $95 \%$ ethanol for the detection of ninhydrin-positive spots prior to peptide elution. When demonstrating peptides which were not be to eluted, a more concentrated spray $(0.2 \%$ ninhydrin in ethanol) was used.

\section{Amino Acid Analysis}

The chymotryptic peptides to be analyzed were cut from seven peptide patterns which represented a total of about $14 \mathrm{mg}$ of digested protein. The cut papers containing the isolated peptides were then rinsed in acetone to remove excess ninhydrin. The normal and variant ninhydrin-positive spots and the corresponding background areas in variant and normal "fingerprints," respectively, were eluted $1.5 \mathrm{hr}$ with $2 \times$ glass-distilled constant boiling $6 \mathrm{~N} \mathrm{HCl}$ according to the procedure described by Chernoff and Liu (1961). The eluate was hydrolyzed for $20 \mathrm{hr}$ at $108 \mathrm{C}$ in evacuated vacuum tubes. After the hydrolysates were concentrated to dryness in an evacuated desiccator containing $\mathrm{KOH}$ and phosphorous pentoxide, and dissolved with distilled $\mathrm{H}_{2} \mathrm{O}$ and dried, they were analyzed on an automatic Technicon amino acid analyzer.

Staining techniques specific for certain amino acids included Ehrlich's stain for tryptophan and Pauly's stain for histidine and tyrosine (Chernoff and Liu, 1961; Easley, 1965). Peptides containing tryptophan could be identified prior to staining by ultraviolet light irradiation. 


\section{Isolation and Tryptic Digestion of Chymotryptic Peptides C-44 and C-44d}

Fifty milligrams of the enzyme were digested with chymotrypsin and the digest was spotted at 50 places $\frac{1}{4}$ inch apart on the origin of a single sheet of chromatography paper (Whatman 3MM). One-dimensional high-voltage electrophoresis was then carried out for $4 \mathrm{hr}$, as described above. The peptides were located by staining guide strips with $0.2 \%$ ninhydrin. The area corresponding to the location of the peptides to be analyzed was cut from the sheet and eluted with $1 \mathrm{~N}$ acetic acid for $4 \mathrm{hr}$. The eluate was concentrated to dryness, taken up in distilled water, spotted on 46 spots $\frac{1}{4}$ inch apart on a single sheet of chromatography paper (Whatman 3MM) and separated by descending chromatography as described above. After $21 \mathrm{hr}$ of chromatography, the separated peptides were located by the guide strip technique, cut from the paper and eluted with $1 \mathrm{~N}$ acetic acid for $4 \mathrm{hr}$, and concentrated to dryness. The dried material was dissolved with $\mathrm{H}_{2} \mathrm{O}$ and concentrated. It was subsequently dissolved with $0.5 \mathrm{ml}$ of $0.2 \mathrm{M}$ ammonium carbonate buffer and digested with $4-5 \%$ trypsin for $12 \mathrm{hr}$ essentially as described by Bahl and Smith (1965). The 12-hr tryptic digest was centrifuged and the supernatant spotted on two papers. These papers were "fingerprinted" and the ninhydrin-positive spots were located with $0.025 \%$ ninhydrin, eluted, hydrolyzed, and analyzed on the amino acid analyzer by the procedures outlined above.

\section{$\mathrm{pH}$ Optimum}

A Beckman Zeromatic $p \mathrm{H}$ meter, with standard reference and glass electrodes, was used for $p \mathrm{H}$ determinations. The $p \mathrm{H}$ of the reaction mixture before and prior to stopping the assay was obtained by using a Metrohm E-300 $p \mathrm{H}$ meter equipped with a standard size combination $p \mathrm{H}$ electrode (Metrohm Ltd. Herisau, Switzerland). Duplicate sets of data were obtained for the normal and variant enzymes isolated from normal and variant erythrocytes.

\section{Heat Inactivation}

Test tubes containing $0.9 \mathrm{ml}$ of an enzyme preparation $(0.4-0.5 \mathrm{mg}$ of enzyme/ml of $10^{-3} \mathrm{M}$ tris- $\mathrm{HCl}, p \mathrm{H}$ 7.5) were swirled in a water bath at the desired temperature for $30 \mathrm{sec}$ and then allowed to incubate for the duration of the inactivation time. The tubes were removed and swirled in an ice bath for $30 \mathrm{sec}$. The precipitated protein was removed by centrifugation at $30,000 \mathrm{~g}$ for $15 \mathrm{~min}$ at $3 \mathrm{C}$. The same concentration of normal and variant protein was carefully maintained for each experiment since protein concentration may alter the rate of inactivation. To eliminate variations, heat inactivation of CA Ia, CA Id, and an equal mixture of the two enzymes was carried out simultaneously. The percent esterase activity remaining was measured by the $\beta$-naphthyl acetate assay. Results were obtained from two experiments.

\section{Immunological Studies}

Antiserum to carbonic anhydrase Ia was prepared by injecting Fraction III A, isolated from normal erythrocytes, into two rabbits as described by Tashian et al. (in press). Serum taken prior to immunization lacked anti-CA Ia activity and the 
antiserum lacked a zone with carbonic anhydrase esterase activity after starch gel electrophoresis. Anti-CA Id serum was not prepared because the quantity of CA Id necessary for its preparation was not available. Immunodiffusion tests were carried out on microscope slides layered with an agar medium as described by Niswander et al. (1964). Antiserum was absorbed with 0.4 vol of separate preparations of CA Ia and CA Id ( $5 \mathrm{mg}$ protein per milliliter stock buffer) for $30 \mathrm{~min}$ at room temperature then overnight at $3 \mathrm{C}$.

\section{RESULTS}

Results of the parallel isolation of CA Ia from blood bank samples and CA Ia and CA Id from heterozygous variant erythrocytes are reported in Table I. The starch gel electrophoretic pattern of the proteins after each isolation step is seen in Fig. 1.

\section{Relative Synthesis of CA Ia and CA Id}

The protein isolated from $1 \mathrm{ml}$ of packed red cells and the percent yield of protein are compared for normal homozygous and variant heterozygous erythrocytes (Table 1). The values for the normal homozygous erythrocytes (averages of two blood bank samples) and for the heterozygous erythrocytes (averages of four samples) are quite similar for Fractions I and II. The normal and variant enzymes (Fraction III A and III B, respectively) were isolated from variant red cells with an average yield of $1.19 \mathrm{mg}$ for CA Ia and $0.65 \mathrm{mg}$ for CA Id per milliliter of packed red cells with a mutant to normal ratio of $0.55: 1$. The total CA I per milliliter of heterozygous red blood cells equals $1.84 \mathrm{mg}$, which is about equal to the $1.77 \mathrm{mg}$ per milliliter isolated from normal erythrocytes. When CA Ia and CA Id were isolated from two samples of untreated (crude) variant hemolysates by preparative starch gel electrophoresis, the same mutant-to-normal ratio was obtained. The total CA II (Fraction III C) per milliliter of red cells isolated from normal and variant erythrocytes equals $0.07 \mathrm{mg}$ and $0.06 \mathrm{mg}$, respectively.

A minor component of CA Ia is present in hemolysates and isolation samples and is designated CA Ia $(+1)$ by Tashian et al. $(1964,1966)$. This minor component is identical to the CA A of Rickli et al. (1964) and Nyman and Lindskog (1964). Carbonic anhydrase $\mathrm{Ia}(+1)$ is seen in Fig 1 migrating anodal to CA Ia in both normal and variant isolation samples (wells 1-4). After isolation of CA Ia and CA Id, the minor components $\mathrm{CA} I a(+1)$ and $\mathrm{CA} \operatorname{Id}(+1)$, respectively, appear in the stock enzyme solutions and are illustrated by starch gel electrophoresis in Fig. 2. Carbonic anhydrase $\mathrm{Id}(+1)$ migrates to the same position relative to $\mathrm{CA}$ Id as $\mathrm{CA} \mathrm{Ia}(+1)$ migrates to $\mathrm{CA}$ Ia. This finding indicates that in the variant hemolysate $\mathrm{CA} \operatorname{Id}(+1)$ overlaps CA Ia. Carbonic anhydrase $\mathrm{Ia}(+1)$ is approximately $6 \%$ of the total CA Ia isolated from normal hemolysates (Tashian et al., 1966). If the same ratio exists for CA Id( +1$)$ and CA Id in variant hemolysates, then CA Ia isolated from $1 \mathrm{ml}$ of packed red cells is contaminated by about $0.04 \mathrm{mg}$ of $\mathrm{CA} \operatorname{Id}(+1)$. This contamination would only slightly alter the mutant-to-normal enzyme ratio in the heterozygous hemolysate and the corrected ratio would be $0.57: 1$. 


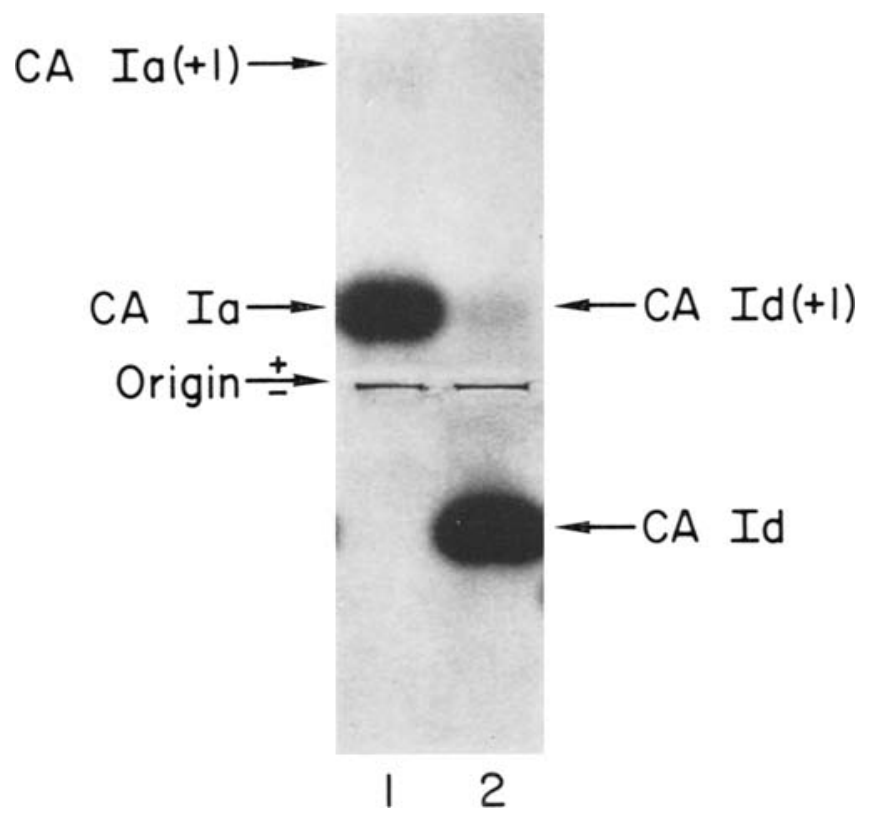

Fig. 2. Protein patterns of purified normal and variant carbonic anhydrase I after starch gel electrophoresis. 1, CA Ia, $1.5 \mathrm{mg}$; and 2, CA Id, $1.5 \mathrm{mg}$. $\mathrm{CA} \mathrm{Ia}(+1)$ and $\mathrm{CA} \operatorname{Id}(+1), 1$ and 2 , respectively, are minor components formed after isolation of $\mathrm{CA}$ Ia and CA Id. Electrophoresis and protein staining conditions were the same as for Fig. 1. 
CA Is

ca Id

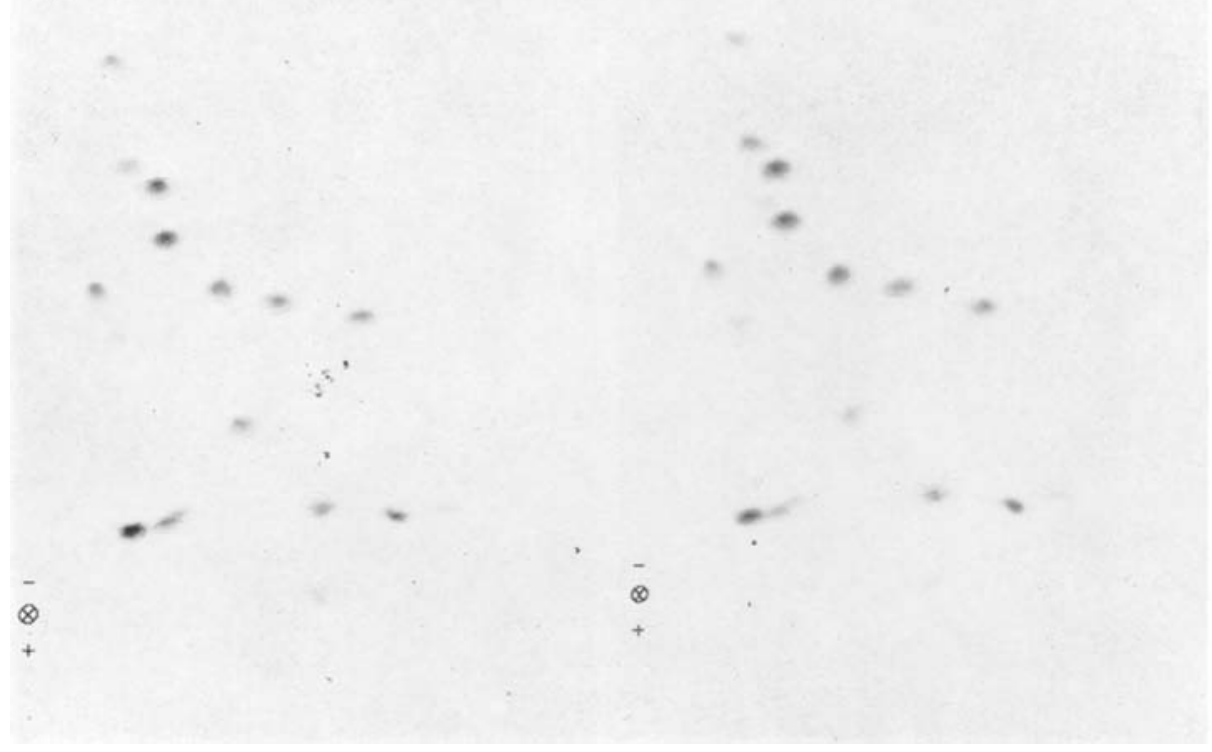

Fig. 3. Tryptic peptide patterns of CA Ia (left) and CA Id (right).

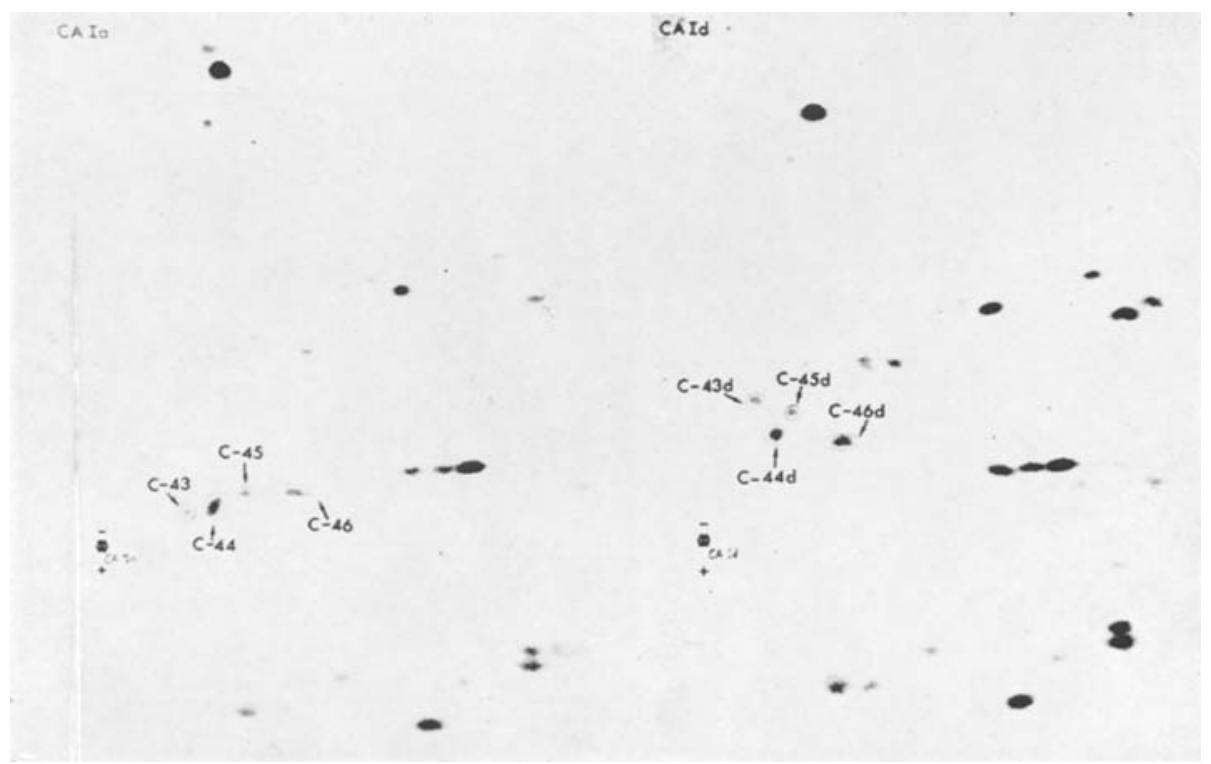

Fig. 4. Chymotryptic peptide maps of CA Ia and CA Id. The peptides that are different in the two maps are indicated. 


\section{Purity of CA Ia and CA Id}

Figures 1 and 2 illustrate that CA Ia and CA Id, when isolated and subjected to starch gel electrophoresis, are electrophoretically quite pure. Small amounts of CA $\mathrm{Ia}(+1)$ and $\mathrm{CA} \operatorname{Id}(+1)$ (Fig. 2) in the protein samples of CA Ia and CA Id, respectively, are presumably not a contaminating factor since $\mathrm{CA} \mathrm{Ia}(+1)$ has the same tryptic peptide pattern (Laurent et al., 1965; Tashian, unpublished), amino acid composition, and $\mathrm{CO}_{2}$ hydratase activity as CA Ia (Nyman and Lindskog, 1964). In theory the same kind of results should be obtained for $\mathrm{CA} \mathrm{Id}(+1)$. The presence of the minor component is apparently caused by a change in the surface charge of the molecule (Nyman and Lidskog, 1964).

When $0.5 \mathrm{mg}$ of CA Ia and CA Id was subjected to starch gel electrophoresis

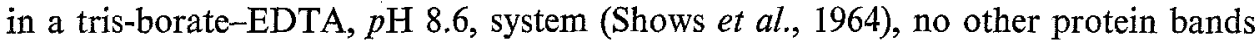
were observed.

\section{Comparative Enzyme Activities During Isolation}

Table I compares the carboxylesterase and $\mathrm{CO}_{2}$ hydratase activities of the enzymes isolated from heterozygous erythrocytes with the enzymes isolated from normal erythrocytes. When the specific esterase and $\mathrm{CO}_{2}$ hydratase activities of normal red cells are compared to variant red cells for each purification step, only small differences are observed. The enzyme activities of CA Id do not deviate significantly from normal values. It is also observed that the enzyme activities of CA II do not differ between normal and variant red cells.

\section{Comparative Peptide Analysis}

\section{Tryptic Peptide Patterns}

No obvious peptide alteration was observed when the tryptic peptide patterns of CA Ia and CA Id were compared (Fig. 3).

\section{Chymotryptic Peptide Patterns}

The undigested tryptic core was further digested with chymotrypsin and a distinct peptide alteration could be detected. Four new peptides appeared on the CA Id peptide map in a region slightly cathodal to the neutral region. The CA Id peptide map also appeared to have lost three or more peptides in the neutral region when compared to the CA Ia map. The peptide differences were separated better when the enzymes were digested initially with chymotrypsin (Fig. 4). Four ninhydrin-positive spots are located in a different position on the CA Id peptide map. The peptides on the CA Ia map are designated C-43, C-44, C-45, and C-46. They have migrated to a new position on the CA Id map and are designated C-43d, C-44d, C-45d, and C-46d. The altered peptides have become more electropositive. Not visible on the chymotryptic peptide maps are many ninhydrin-positive spots which stain too weakly to be seen on the photographic print. When the chymotryptic core of CA Ia and CA Id was digested with trypsin, no peptide differences were observed. 
The CA Ia and CA Id chymotryptic peptide maps were tested with Ehrlich's stain for tryptophan and Pauley's stain for histidine and tyrosine. Results of the two specific staining procedures were the same for CA Ia and CA Id peptide maps. Of interest, however, is the fact that C-45, C-46, C-45d, and C-46d were positive for Ehrlich's stain, while C-43, C-44, C-43d, and C-44d were negative. After staining with ninhydrin, C-43, C-44, C-43d, and C-44d were initially yellowish blue, while C-45, C-46, C-45d, and C-46d were the typical blue color. It has been reported (Nakashima et al., 1966; Matsubara and Smith, 1963; Helinski and Yanofsky, 1962) that peptides with amino-terminal glycine initially appear yellow, yellow-blue, or green-blue in color. Since ninhydrin reacts with the $\alpha$-amino group of the amino-terminal amino acid of peptides, these results would suggest that C-43, C-44, C-43d, and C-44d have an amino-terminal amino acid different from C-45, C-46, C-45d, and C-46d.

\section{Peptic Peptide Patterns}

One additional peptide on the CA Id map appeared to be the only difference between CA Ia and CA Id peptic peptide patterns (Fig. 5). The normal peptide has not been resolved and could be obscured by overlapping peptides or by its remaining in the core.

\section{The Amino Acid Substitution}

The amino acid compositions of the four normal and four variant chymotryptic peptides are compared in Table II. Peptides C-43 and C-43d are each composed of nine amino acids. The variant peptide has, however, acquired a lysine and lost a threonine. Peptides C-44 and C-44d are larger peptides composed of 16 amino acids. Peptide C-44d has also acquired one lysine and lost one threonine. Peptide C-45 differs from C-43 and C-46 differs from C-44 only in the presence of the tryptophan detected by Ehrlich's stain. Acid hydrolysis destroys tryptophan, which accounts for its absence after the amino acid analysis of C-45, C-45d, C-46, and C-46d. The exact number of tryptophan residues is, therefore, not known. The amino acid substitution is repeated for C-45 and C-45d and again for C-46 and C-46d. It is concluded from these data that a lysine residue has been substituted for a threonine residue in the variant enzyme. The involvement of four peptides instead of an expected single peptide is probably the result of partial chymotryptic digestion and a model to explain this phenonenon will be presented below.

\section{Amino Acid Analysis of the Tryptic Peptides of C-44 and C-44d}

To gain further evidence that the postulated substitution is correct, the peptides C-44 and C-44d were digested with trypsin. One predicts that the fingerprints will be different with at least two peptides possible for $\mathrm{C}-44$, since lysine is present, and at least three possible peptides for C-44d, since two lysines are present. Figure 6 illustrates the results of tryptic digestion of these two peptides. It is observed that the fingerprint of C-44 is, in fact, different from C-44d. Trypsin, however, did not completely digest C-44 and C-44d, and the remainder of the intact peptides are located in their usual positions after electrophoresis and chromatography. The tryptic peptides of C-44 


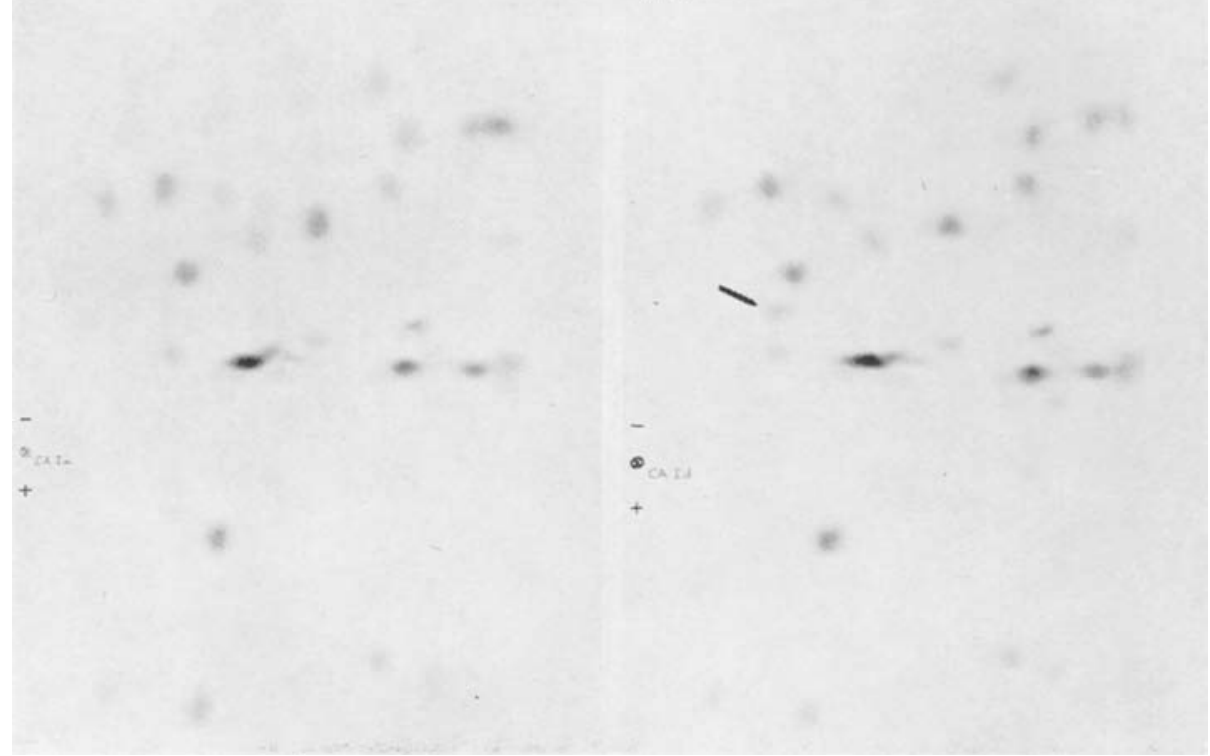

Fig. 5. Peptide maps of CA Ia (left) and CA Id (right) after digestion with pepsin. The additional CA Id peptide is indicated.

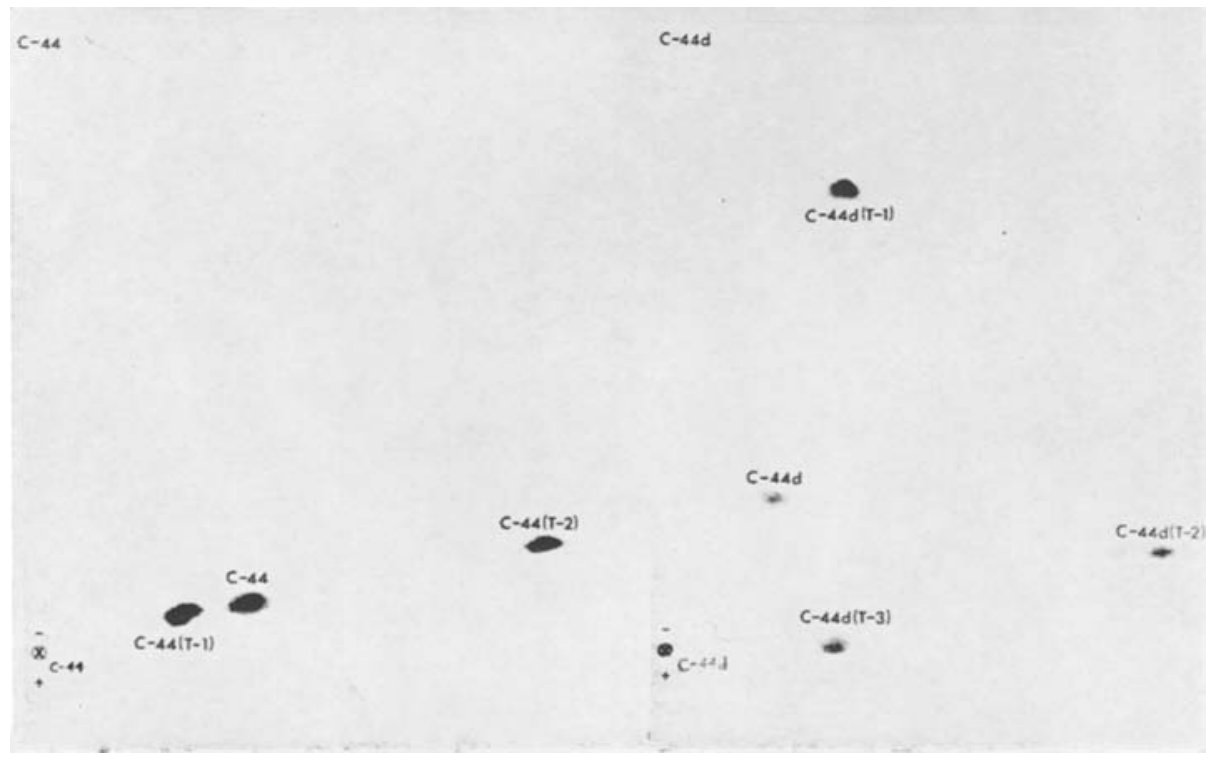

Fig. 6. Tryptic peptide patterns of chymotryptic peptides C-44 and C-44d. 

are designated $\mathrm{C}-44(\mathrm{~T}-1)$ and $\mathrm{C}-44(\mathrm{~T}-2)$. For $\mathrm{C}-44 \mathrm{~d}$, the tryptic peptides are labeled $\mathrm{C}-44 \mathrm{~d}(\mathrm{~T}-1), \mathrm{C}-44 \mathrm{~d}(\mathrm{~T}-2)$, and $\mathrm{C}-44 \mathrm{~d}(\mathrm{~T}-3)$. It is predicted that one tryptic peptide will be the same for C-44 and C-44d, and this appears to be the case for the corresponding (T-2) peptides.

Table III lists the amino acid composition of each peptide. The undigested C-44 and $\mathrm{C}-44 \mathrm{~d}$ peptides have the same composition as before trypsin digestion, and $\mathrm{C}-44 \mathrm{~d}$

Table II. Amino Acid Composition of Normal and Variant Chymotryptic Peptides ${ }^{a}$

\begin{tabular}{|c|c|c|c|c|c|c|c|c|}
\hline Amino acid & C-43 & $C-43 d$ & C-44 & $C-44 d$ & C-45 & $C-45 d$ & C-46 & $C-46 d$ \\
\hline Lysine & $0.0(0)$ & $0.7(1)$ & $0.7(1)$ & $1.7(2)$ & $0.0(0)$ & $0.7(1)$ & $0.9(1)$ & $1.7(2)$ \\
\hline Histidine & $\overline{2.3(2)}$ & $\overline{2.2(2)}$ & $\overline{2.0(2)}$ & $\overline{2.0(2)}$ & $\overline{1.9(2)}$ & $\overline{2.3(2)}$ & $\overline{2.3(2)}$ & $\overline{2.4(2)}$ \\
\hline Aspartic acid & $0.8(1)$ & $1.0(1)$ & $2.0(2)$ & $2.0(2)$ & $0.8(1)$ & $0.7(1)$ & $2.1(2)$ & $2.0(2)$ \\
\hline Threonine & $1.0(1)$ & $0.0(0)$ & $1.7(2)$ & $0.9(1)$ & $1.4(1)$ & $0.1(0)$ & $1.8(2)$ & $0.9(1)$ \\
\hline Serine & $\overline{1.9(2)}$ & $\overline{2.0(2)}$ & $\overline{2.2(2)}$ & $\overline{2.3(2)}$ & $\overline{1.9(2)}$ & $\overline{1.7(2)}$ & $\overline{1.7(2)}$ & $\overline{1.6(2)}$ \\
\hline Glutamic acid & $2.0(2)$ & $2.0(2)$ & $2.2(2)$ & $2.1(2)$ & $2.0(2)$ & $1.6(2)$ & $1.8(2)$ & $2.0(2)$ \\
\hline Glycine & $0.8(1)$ & $0.8(1)$ & $2.0(2)$ & $2.4(2)$ & $0.8(1)$ & $0.7(1)$ & $2.2(2)$ & $2.1(2)$ \\
\hline Valine & & & $2.0(2)$ & $2.0(2)$ & & & $1.9(2)$ & $2.0(2)$ \\
\hline Tyrosine & & & $0.8(1)$ & $0.8(1)$ & & & $0.9(1)$ & $0.7(1)$ \\
\hline Tryptophan $^{b}$ & - & - & - & - & + & + & + & + \\
\hline Residues & 9 & 9 & 16 & 16 & 10 & 10 & 17 & 17 \\
\hline Yield & $2 \%$ & $2 \%$ & $6 \%$ & $9 \%$ & $2 \%$ & $1 \%$ & $5 \%$ & $4 \%$ \\
\hline
\end{tabular}

a The composition of each peptide from CA Ia (C-43-C-46) and CA Id (C-43d-C-46d) is given as the molar ratio of the amino acids present without correction for losses during acid hydrolysis. Values represent the average from two separate isolations rounded to the nearest 0.1 mole. Residues present as 0.1 mole or less have been omitted. The assumed number of residues is given in parentheses.

${ }^{b}$ The presence of tryptophan was determined by Ehrlich's stain.

again reflects the amino acid substitution. Peptide C-44 (T-1) differs from C-44 only in the absence of tyrosine, while C-44 (T-2) is free tyrosine. Since trypsin acts at the $\mathrm{COOH}$-terminal of lysine, tyrosine is $\mathrm{COOH}$-terminal in this peptide and lysine is penultimate to it. Peptide C-44d (T-1) contains one lysine, two serines, and one glycine. This peptide, after ninhydrin staining, turns the characteristic yellowish-blue color of a peptide containing amino-terminal glycine (cf. Nakashima et al., 1966; Matsubara and Smith, 1963; and Helinski and Yanofsky, 1962). The remaining C-44d tryptic peptides have the typical blue color. The fact that $\mathrm{C}-44 \mathrm{~d}$ initially exhibits a yellowish-blue color would suggest that perhaps $C-44 d(T-1)$ is located at the aminoterminal of C-44d. The C-44d (T-2) "peptide" is free tyrosine.

\section{Comparative Properties of the Normal and Variant Enzymes}

The purpose of the following kinetic measurements was to compare CA Ia with CA Id isolated from heterozygous variant erythrocytes. Carbonic anhydrase Ia isolated from homozygous normal erythrocytes was a control and in all instances gave similar results to CA Ia isolated from heterozygous variant erythrocytes. The 
esterase activity utilizing $\beta$-naphthyl acetate as the substrate was the standard enzyme assay for the kinetic studies.

\section{Specific Enzyme Activities}

No differences in the esterase activity toward $\beta$-naphthyl acetate or $\mathrm{CO}_{2}$ hydratase activity were detected between CA Ia and CA Id (Table I). The carboxylesterase activity of CA Id toward $p$-nitrophenyl acetate $(0.34 \mu$ mole $p$-nitrophenol formed

Table III. Composition of Peptides After Tryptic Digestion of C-44 and C-44d ${ }^{a}$

\begin{tabular}{|c|c|c|c|c|c|c|}
\hline Amino acid & C-44 & C-44 (T-1) & $\mathrm{C}-44(\mathrm{~T}-2)$ & C-44d & C-44d (T-1) & C-44d (T-2) \\
\hline Lysine & $0.9(1)$ & $0.6(1)$ & & $1.6(2)$ & $1.2(1)$ & \\
\hline Histidine & $\overline{2.1(2)}$ & $1.9(2)$ & & $\overline{1.8(2)}$ & & \\
\hline Aspartic acid & $2.0(2)$ & $2.0(2)$ & & $2.0(2)$ & & \\
\hline Threonine & $2.0(2)$ & $1.8(2)$ & & $0.9(1)$ & & \\
\hline Serine & $\overline{1.9(2)}$ & $2.4(2)$ & & $\overline{2.4(2)}$ & $1.8(2)$ & \\
\hline Glutamic acid & $2.4(2)$ & $2.2(2)$ & & $2.3(2)$ & & \\
\hline Glycine & $2.0(2)$ & $2.0(2)$ & & $2.4(2)$ & $0.8(1)$ & \\
\hline Valine & $2.2(2)$ & $1.8(2)$ & & $2.0(2)$ & & \\
\hline Tyrosine & $0.6(1)$ & $0.0(0)$ & $1.0(1)$ & $0.8(1)$ & & $1.0(1)$ \\
\hline Residues & 16 & 15 & 1 & 16 & 4 & 1 \\
\hline
\end{tabular}

a The composition of tryptic peptides from $\mathrm{C}-44$ and $\mathrm{C}-44 \mathrm{~d}$ is given as the molar ratio of the amino acids without correction for losses during acid hydrolysis. Values are rounded to the nearest 0.1 mole. Residues present as 0.1 mole or less have been omitted. The assumed number of residues is given in parentheses.

per minute per milligram) was not significantly different from the activity of CA Ia from variant or normal erythrocytes $(0.33 \mu$ mole $p$-nitrophenol per minute per milligram).

\section{$\mathrm{K}_{\mathrm{m}}$ Determinations}

The $K_{m}$ for CA Ia and CA Id, isolated from variant erythrocytes, were 5.0 and 4.5 $\times 10^{-3} \mathrm{M}$, respectively (Fig. 7). The $K_{m}$ of CA Ia from a normal homozygote was $4.5 \times 10^{-3} \mathrm{M}$. The results represent values from two separate preparations of CA Ia, from a normal homozygote, and CA Ia and CA Id from the heterozygous individual.

\section{$\mathrm{p} H$ Optimum}

The normal and variant enzymes, when tested with the $0.05 \mathrm{M}$ tris- $\mathrm{HCl}$ assay buffer, had the same $p \mathrm{H}$ optimum at 8.7 when the $p \mathrm{H}$ was measured at $37 \mathrm{C}$ (assay temperature) and a $p \mathrm{H}$ optimum at 9.0 when the $p \mathrm{H}$ was measured at $22 \mathrm{C}$ (Fig. 8). Using a $0.025 \mathrm{M}$ glycine- $\mathrm{NaCl}-\mathrm{NaOH}$ buffer, $\mathrm{CA}$ Ia and $\mathrm{CA}$ Id demonstrated a broad peak with an optimum around $p \mathrm{H} 9.1$ (at $37 \mathrm{C}$ ) or 9.3 (at $22 \mathrm{C}$ ). At each point, the $p \mathrm{H}$ of the reaction mixture just prior to assay was equal to the value obtained before stopping the assay with acetazolamide. The activity of the enzymes in the tris buffer is approximately $15 \%$ higher than in the glycine buffer. 
Fig. 7. Lineweaver-Burk plots of CA Ia and $\mathrm{CA}$ Id. The standard $\beta$-naphthyl acetate assay was employed except that the concentration of recrystallized $\beta$-naphthyl acetate was varied from 0.3 to $1.25 \mathrm{~mm}$. The $K_{m}$ of CA Id equals $4.5 \times$ $10^{-3} \mathrm{M}$ and the $K_{m}$ of CA la equals $5.0 \times 10^{-3} \mathrm{M}$. Assays were done with different concentrations of CA Ia $\left(8.3 \times 10^{-3} \mu\right.$ mole $)$ and CA Id $(7.7 \times$ $10^{-3} \mu$ mole); the specific activities of the normal and variant proteins were the same at the two concentrations. CA Ia. O CA Id.
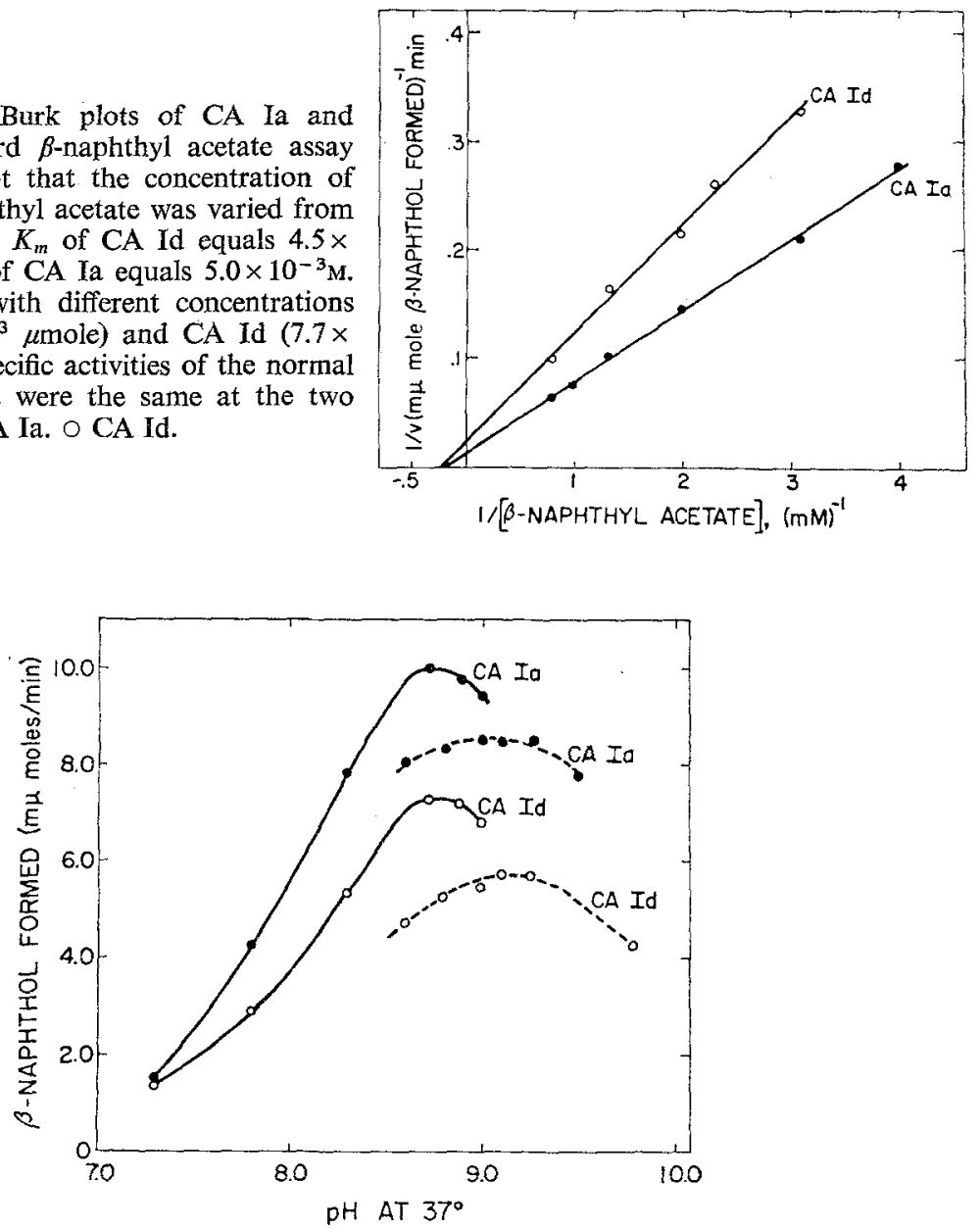

Fig. 8. $p \mathrm{H}$ optimum of $\mathrm{CA}$ Ia and CA Id. Activity was measured under the standard $\beta$-naphthyl acetate conditions with the standard tris- $\mathrm{HCl}$ buffer and, in addition, a glycine- $\mathrm{NaCl}-\mathrm{NaOH}$ buffer at final concentrations in the assay equal to $0.05 \mathrm{M}$ and $0.025 \mathrm{M}$, respectively. The $p \mathrm{H}$ of the buffers was measured at $37 \mathrm{C}$, the assay temperature. $\mathrm{CA}$ Id assays with both buffers contained $28 \%$ less protein than CA Ia assays; equal protein concentrations of CA Ia and CA Id gave similar results. Solid circles represent $\mathrm{CA}$ Ia and open circles CA Id. - - - O- Tris buffer. - - - - O- - Glycine buffer.

\section{Heat Inactivation}

Normal and variant enzyme preparations, at identical protein concentrations, were incubated for $5 \mathrm{~min}$ at temperatures ranging from 37 to $60 \mathrm{C}$. At $55 \mathrm{C} \mathrm{CA}$ Id begins to lose activity and at $60 \mathrm{C}$ most activity was lost (Fig. 9). The activity loss of CA Ia was slightly less pronounced at the highest temperatures. 
When equal amounts of CA Ia and CA Id were incubated at $57 \mathrm{C}$ for the indicated times, and the hydrolysis of $\beta$-naphthyl acetate subsequently measured at $37 \mathrm{C}$, the mutant was found to be noticeably more heat labile than the normal enzyme (Fig. 10). The half-life of the mutant is about $8 \mathrm{~min}$, in contrast to the $19 \mathrm{~min}$ half-life of the normal. A $50: 50$ mixture of the two enzymes yielded the expected intermediate curve.

\section{Acetazolamide Inhibition}

Acetazolamide (Diamox, Lederle Laboratories) is a specific inhibitor for both the hydrase and esterase activities of carbonic anhydrase (Tashian et al., 1964; Malm-

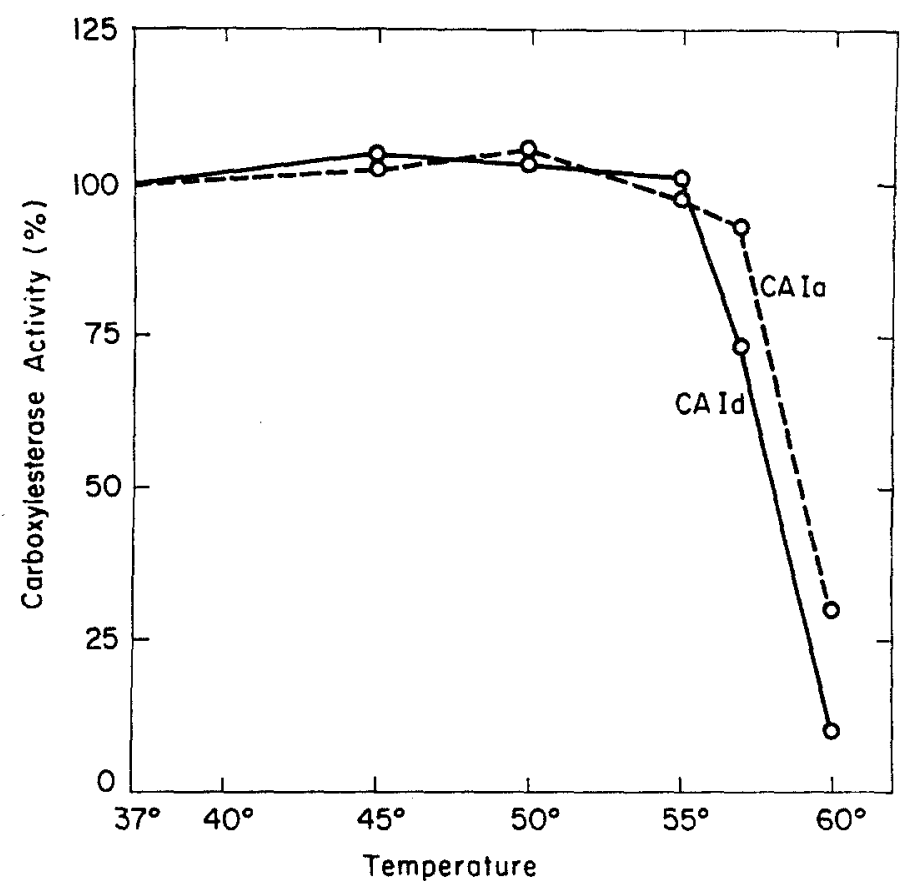

Fig. 9. Heat stability of CA Ia and CA Id. Following incubation for $5 \mathrm{~min}$ at the temperatures shown, the enzymes were assayed for residual $\beta$-naphthyl acetate activity. $0--0 \mathrm{CA}$ Ia. $0-0 \mathrm{CA}$ Id.

ström et al., 1964; Pocker and Stone, 1967) and is used to stop the enzyme assays. The esterase activity of CA Ia and CA Id toward $\beta$-naphthyl acetate was equally inhibited (Fig. 11) at concentrations of acetazolamide ranging from $1.5 \times 10^{-3}$ to $1.5 \times 10^{-8} \mathrm{M}$ (complete inhibition to no inhibition). Fifty percent inhibition of $\mathrm{CA} \mathrm{Ia}$ and CA Id equals $3.1 \times 10^{-6} \mathrm{M}$.

\section{Immunological Studies}

Immunodiffusion studies demonstrated that purified CA Ia and CA Id were not immunologically different since a single continuous precipitin band without spurring was observed between outer wells containing $0.01 \mathrm{mg}$ of $\mathrm{CA} \mathrm{Ia}$ and CA Id and the center well containing unabsorbed anti-human CA Ia serum. 


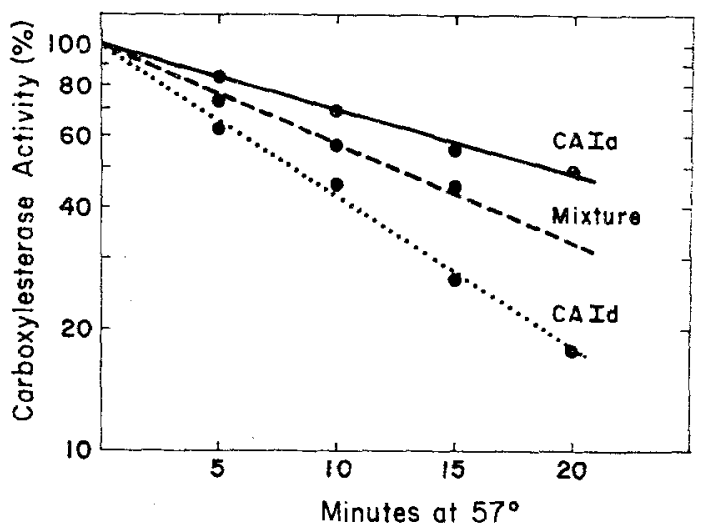

Fig. 10. Heat inactivation of $\mathrm{CA}$ Ia and $\mathrm{CA}$ Id at 57 C. Equal concentrations $\left(0.4 \mathrm{mg}\right.$ protein $/ \mathrm{ml} 10^{-3} \mathrm{M}$ tris- $\mathrm{HCl}, p \mathrm{H} \mathrm{7.5)}$ of CA Ia, CA Id, and a $50: 50$ mixture of CA Ia and CA Id were incubated simultaneously for the times indicated. After incubation and centrifugation, aliquots $(0.3 \mathrm{ml})$ of the supernatant fraction were added to the standard $\beta$-naphthyl acetate reaction mixture for assay. - CA Ia. - - . Mixture. CA Id.

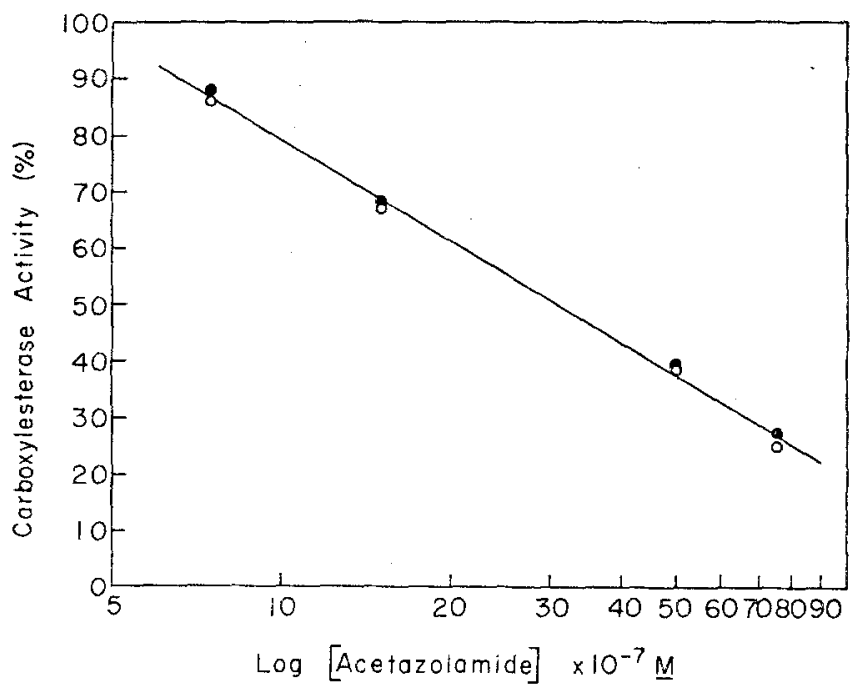

Fig. 11. Comparative inhibition of the esterase activity of CA $\mathrm{Ia}$ and $\mathrm{CA}$ Id by acetazolamide. Without altering reagent concentrations or total volume of the $\beta$-naphthyl acetate assay mixture, the appropriate concentration of acetazolamide was added to the reaction mixture, without substrate, and allowed to incubate for $5 \mathrm{~min}$ at $37 \mathrm{C}$; the assay was then conducted as described. The protein concentrations were essentially the same for CA Ia and CA Id. Solid circles represent $\mathrm{CA}$ Ia and open circles CA Id. 
Anti-human CA Ia serum was absorbed by mixing it with CA Ia or CA Id and, after centrifugation, tested against CA Ia and CA Id. If the structural alteration of CA Id causes an altered antigenic site, then antiserum absorbed with CA Id should still contain CA Ia antibodies to the normal unaltered site. Antiserum absorbed with CA Id was tested by immunodiffusion in an attempt to demonstrate the formation of a precipitin band against CA Ia not formed against CA Id. This would be expected if antigenic sites have been altered in CA Id. No precipitin band was formed against CA Ia after absorption with CA Id. However, if only a single antigenic site had been altered in CA Id, precipitation of CA Ia could not occur even though a specific antibody was directed against it because lattice formation could not take place with only a single antigenic site per molecule. If an antibody specific for the CA Ia site altered in CA Id were, in fact, present in the absorbed antiserum, it would complex with CA Ia and cause an alteration in mobility after starch gel electrophoresis. When the absorbed antiserum was added to purified CA Ia and electrophoresis carried out on the mixture, no effect on the mobility of CA Ia could be detected. These immunological comparisons have not revealed any differences in antigenic properties between CA Ia and CA Id.

\section{DISCUSSION}

\section{The Amino Acid Substitution}

Since CA Id travels to a position more cathodal than CA Ia after electrophoresis, it is predicted that one peptide would gain a positive charge after peptide pattern analysis. However, after chymotryptic digestion of the normal and variant enzymes, four variant peptides with different compositions migrated more cathodally than their corresponding CA Ia peptides. The amino acid compositions of the normal and variant chymotryptic peptides indicated that partial chymotryptic digestion was the probable reason for the involvement of four peptides, each showing the threonine to lysine substitution. Partial chymotryptic hydrolysis is a common occurrence, and peptides produced in this way have been used to determine and confirm the amino acid sequence of a segment of the polypeptide chain containing the overlapping peptides (Matsubara and Smith, 1963; Hirs, Stein, and Moore, 1956).

The presence of lysine in the normal and variant peptides (Table II) makes it possible to break the peptides, by tryptic digestion, into smaller components for analysis. It was predicted that since C- $44 \mathrm{~d}$ contained two lysine residues and C-44 only one, the tryptic peptide maps would be different. Since this was found to be true, it provides further evidence that lysine had been substituted for threonine.

Theoretically, if a lysine has been substituted, a peptide difference should be observed after tryptic digestion of the variant enzyme. A difference was not observed on tryptic peptide maps. It was found that the amino acid alteration in CA Id was located in a segment of the protein, resistant to tryptic digestion, which makes up the core. Amino acid analysis of trypsin-resistant cores from hemoglobin (Baglioni, 1962) and carbonic anhydrase (Tashian, unpublished) in fact contain lysine and arginine residues. The peptides in question may also be obscured by other ninhydrin- 
positive spots on the peptide map or precipitated at the origin (Helinski and Yanofsky, 1962) by the acidic $\mathrm{pH}$ of chromatography solvents.

The amino acid exchange of threonine by lysine has been previously reported for hemoglobin $\mathrm{D}_{\text {Ibadan }}$ (Watson-Williams et al., 1965). This is the first instance of this particular substitution in $\mathrm{Hb} \mathrm{A}$ and, like CA Id, also involved the trypsinresistant core. This amino acid change is compatible with a single nucleotide substitution, from cytosine to adenine, between a pair of nucleotide RNA codons designated to code for threonine (ACA; ACG) and lysine (AAA; AAG) (Nirenberg et al., 1965; Sö1l et al., 1965).

\section{Suggested Amino Acid Order of the Chymotryptic Peptides}

Until the sequence of the chymotryptic peptides is completed, a working model of the relative amino acid order is proposed in Fig. 12. The model is based on the previously stated assumption that partial chymotryptic digestion occurred, and on the experimental results which include amino acid compositions of the normal and variant

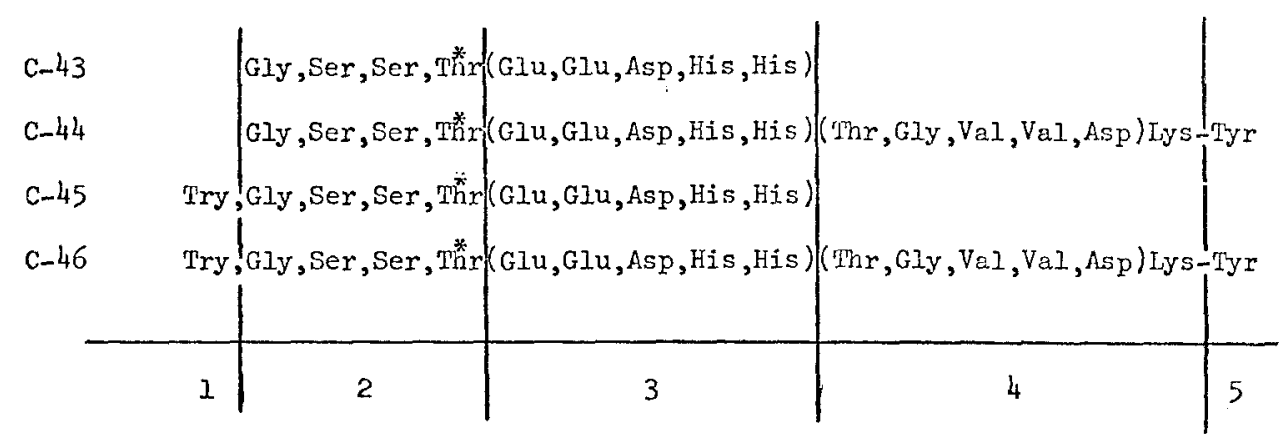

Fig. 12. Model illustrating the relative position of the amino acids on the polypeptide segment composed of C-43, C-44, C-45, and C-46. The polypeptide chain is divided into five sections. The location, amino acid composition, and amino acid order of each section are based on the compositions of chymotryptic and tryptic peptides and ninhydrin color reactions. The order of the amino acid residues outside parentheses, and set off by commas, has not been determined by sequence studies but is suggested from the data. The order of amino acid residues within parentheses, and set off by commas, has no experimental basis. *Proposed site of the amino acid substitution (Thr $\rightarrow$ Lys).

chymotryptic peptides, the composition of the tryptic peptides of C-44 and C-44d, and the staining characteristics of each peptide. We are concerned with a large peptide representing approximately $7 \%$ of the protein and containing C-43, C-44, C-45, and C-46. This large peptide has been arbitrarily cut into five sections (Fig. 12), for reasons which will become clear in the following discussion. Tryptic digestion of C-44 yields two separable peptides by peptide mapping. The composition of one peptide is made up of Sections 2, 3, and 4, while free tyrosine, the other ninhydrin-positive spot, is Section 5. The composition data (Table III) indicate that lysine and tyrosine are, respectively, the penultimate and COOH-terminal amino acids of C-44. Peptide $\mathrm{C}-44 \mathrm{~d}$ was separated into three peptides after tryptic digestion. The tetrapeptide C-44d (T-1) (Fig. 6 and Table III) is composed of one glycine, two serine, and one 
lysine residues, and it is probably at the amino-terminal end of C-44d for two reasons. Peptides C-44, C-44 (T-1), C-44d, and C-44d (T-1) give a characteristic yellowish-blue color when stained with ninhydrin, whereas peptides C-44 (T-2), C-44d (T-2), and $\mathrm{C}-44 \mathrm{~d}(\mathrm{~T}-3)$ are stained blue after ninhydrin. This probably indicates that glycine is the amino-terminal residue (cf. Nakashima et al., 1966; Matsubara and Smith, 1963; Helinski and Yanofsky, 1962) in C-44, C-44 (T-1), C-44d, and C-44d (T-1) but not in C-44 (T-2), C-44d (T-2), and C-44d (T-3). The second reason is based on arguments involving $\mathrm{C}-43$ which will be taken up below. If $\mathrm{C}-44 \mathrm{~d}$ (T-1) is at the amino-terminal end in C-44d, Section 2 is composed of the C-44d (T-1) peptide except that the normal threonine has replaced the variant lysine. It is postulated that this threonine is at the site of the amino acid substitution. This would indicate that Section 2 is common to all the peptides. Peptide C-43, the smallest peptide, has been divided into two sections, designated 2 and 3, which are postulated to be identical for all the peptides. Section 2 is at the amino-terminal end because C-43 and C-43d also have the yellowish-blue color after staining with ninhydrin and contain only one glycine residue. Section 2 cannot be on the COOH-terminal side of $\mathrm{C}-43$ because threonine would be the $\mathrm{COOH}$-terminal residue and usually not subject to the action of chymotrypsin. Section 3, containing the remaining amino acids in $\mathrm{C}-43$, is then placed COOH-terminal to Section 2. With reference to $\mathrm{C}-44$, if the ordering of $\mathrm{C}-43$ is correct and Sections 2 and 3 are common to both C-44 and C-43, then Section 4 would logically follow by subtraction. Except for the presence of tryptophan, peptides C-45 and C-46 are identical in composition to C-43 and C-44, respectively (Table II). After ninhydrin staining, C-45 and C-46 are blue in color whereas C-43 and C-44 are yellow-blue, indicating different amino-terminal amino acids. Tryptophan is not present in $\mathrm{C}-43$ and $\mathrm{C}-44$; therefore, it is assigned to Section 1 as the amino terminus of $\mathrm{C}-45$ and $\mathrm{C}-46$. The remainder of $\mathrm{C}-45$ and $\mathrm{C}-46$ have the same amino acid composition as C-43 and C-44, respectively, and on this rationale are assigned the order of the latter. Tryptophan must be at either the amino- or COOH-terminal end of the peptide because of the characteristics of chymotryptic hydrolysis. It is assumed here that only one tryptophan is present and at the same location in both C-45 and C-46.

Clearly, this model is quite tentative; however, it serves to place groups of amino acids in some sort of logical order. When the sequence of carbonic anhydrase $I$ is complete, the exact location of the amino acid substitution in CA Id should be easier to determine as a result of the model. The fact that the segment of the polypeptide chain encompassing C-43, C-44, C-45, and C-46 contains 1 of 6 total tryptophan residues, 2 of 11 total histidine residues, and 1 of 8 total tyrosine residues will also certainly play an important part in locating the substitution. Nyman et al. (1966) have sequenced the last 19 amino acids from the C-terminal end of human erythrocyte CA I. The amino acid compositions of C-43, C-44, C-45, and C-46 preclude the possibility that they are located in this sequenced $\mathrm{C}$-terminal part of CA I.

\section{Synthesis of the Variant Enzyme}

The isolation data (Table I) demonstrate that the amount of variant enzyme, isolated from heterozygous erythrocytes, is not equal to the normal allelic product (CA Ia). 
In fact, almost twice as much normal as variant enzyme is present (about $65 \%$ normal; $35 \%$ variant). This difference is probably caused by an alteration of protein synthesis and not an isolation artifact. There are two facts which support the differential synthesis hypothesis: (1) the total CA I isolated from heterozygous erythrocytes equals the CA I isolated from an equal amount of normal red cells, and (2) when CA Ia and CA Id were isolated from untreated (crude) heterozygous hemolysates by preparative starch gel electrophoresis, the mutant-to-normal ratio was equal to the ratio after enzyme isolation.

A quantitative difference between normal and variant forms in heterozygotes has been reported for another carbonic anhydrase mutant, $\mathrm{CA} \mathrm{Ic}_{\text {Guam }}$ (Tashian et al., 1966), where a variant-to-normal ratio of 0.56:1 was found. Boyer, Hathaway, and Garrick (1964) list 10 different hemoglobin variants which differ structurally and quantitatively with the heterozygotes exhibiting more normal adult hemoglobin than the variant form. In the minor hemoglobin component, the normal amount of hemoglobin $\mathrm{A}_{2}$ exceeds that of the structural variant in heterozygotes (Horton et al., 1961). The human myoglobin variant, $\mathrm{Mb}_{\mathrm{Aberdeen}}$, is also expressed in a normal-to-variant ratio of $3: 1$ in heterozygotes (Boyer et al., 1963).

\section{Comparative Properties of CA Ia and CA Id}

The substitution of this threonine in CA Id has apparently altered the thermostability of the variant enzyme when it is exposed to high temperatures (Figs. 9 and 10). Under the usual conditions of storage and handling, the stability of the variant enzyme did not differ from that of the normal. It would appear that the weak attractive forces which maintain the three-dimensional configuration are sufficient to sustain the stability of the variant enzyme under physiological conditions. Decreased thermostability of mutant enzymes has been observed quite often since the original work of Maas and Davis (1952) on a mutant pantothenic acid synthetase in Escherichia coli (cf. Fincham, 1960). Yanofsky (1963) and Kirkman et al. (1964), respectively, have described a wide range of thermolabile mutants for tryptophan synthetase in Escherichia coli and glucose 6-phosphate dehydrogenase in man.

\section{Immunochemical Aspects}

Boerma and Huisman (1964) reported that a change of only one amino acid in hemoglobins $\mathrm{S}$ and $\mathrm{C}$ is detectable immunologically. Using immunodiffusion techniques, they demonstrated the formation of specific anti-S and anti-C antibodies in the rabbit. On the basis of these results, anti-human CA Ia serum was prepared in rabbits to determine possible immunological differences between $\mathrm{CA}$ Ia and CA Id. The results indicated that the primary structural alteration in the variant enzyme did not give rise to gross alterations in the secondary or tertiary structure of the molecule, or to a sufficient change in configuration at the point of substitution to be recognized as antigenically different by antibodies in the two antisera tested. 


\section{ACKNOWLEDGMENTS}

To Dr. Richard E. Tashian, in whose laboratory this work was carried out, I would like to extend my sincere gratitude for his valuable suggestions, guidance, and continued interest. I am indebted to Dr. G. J. Brewer for his assistance in collecting blood from the individual with the variant enzyme; to Dr. D. C. Shreffler for his counsel and laboratory facilities in the immunological studies; and to Drs. R. H. Davis, M. J. Hunter, and D. L. Rucknagel for their constructive suggestions. The laboratory assistance of Mrs. Ya-Shiou L. Yu and Miss Sharon K. Riggs is gratefully acknowledged.

\section{REFERENCES}

Armstrong, J. McD., Myers, D. V., Verpoorte, J. A., and Edsall, J. T. (1966). Purification and properties of human erythrocyte carbonic anhydrases. J. Biol. Chem. 241: 5137.

Baglioni, C. (1962). Analysis of the human adult hemoglobin "core". Biochim. Biophys. Acta 65: 389.

Bahl, O. P., and Smith, E. L. (1965). Amino acid sequence of rattlesnake heart cytochrome $c . J$. Biol. Chem. 240: 3585 .

Boerma, F. W., and Huisman, T. H. J. (1964). Serologic investigations of human hemoglobins. II. Antibodies produced by isolated human hemoglobin types with known structural differences. J. Lab. Clin. Med. 63: 264.

Boyer, S. H., Fainer, D. C., and Naughton, M. A. (1963). Myoglobin: inherited structural variation in man. Science 140: 1228.

Boyer, S. H., Hathaway, P., and Garrick, M. D. (1964). Modulation of protein synthesis in man: An in vitro study of hemoglobin synthesis by heterozygotes. Cold Spring Harbor Symp. Quant. Biol. 29: 333.

Chernoff, A. I., and Liu, J. C. (1961). The amino acid composition of hemoglobin. II. Analytical technics. Blood 17: 54.

Easley, C. W. (1965). Combinations of specific color reactions useful in the peptide mapping technique. Biochim. Biophys. Acta 107: 386.

Edsall, J. T., Mehta, S., Myers, D. V., and Armstrong, J. McD. (1966). Structure and denaturation of human carbonic anhydrases in urea and guanidine hydrochloride solutions. Biochem. $Z$. 345: 9 .

Eggstein, M., and Kreutz, F. H. (1955). Vergleichende Untersuchungen zur quantitativen Eiweissbestimmung im Liquor und eiweissarmen Losungen. Klin. Wochschr. 33: 879.

Fincham, J. R. S. (1960). Genetically controlled differences in enzyme activity. Adv. in Enzymology 22: 1 .

Helinski, D. R., and Yanofsky, C. (1962). Peptide pattern studies on the wild-type A protein of the tryptophan synthetase of Escherichia coli. Biochim. Biophys. Acta 63: 10.

Hirs, C. H. W., Stein, W. H., and Moore, S. (1956). Peptides obtained by chymotryptic hydrolysis of performic acid-oxidized ribonuclease. A partial structural formula for the oxidized protein. J. Biol. Chem. $221: 151$.

Horton, B., Payne, R. A., Bridges, M. T., and Huisman, T. H. J. (1961). Studies on an abnormal minor hemoglobin component $\left(\mathrm{Hb}-\mathrm{B}_{2}\right)$. Clin. Chim. Acta 6: 246.

Katz, A. M., Dreyer, W. J., and Anfinsen, C. B. (1959). Peptide separation by two-dimensional chromatography and electrophoresis. J. Biol. Chem. 234: 2897.

Kirkman, H. N., McCurdy, P. R., and Naiman, J. L. (1964). Functionally abnormal glucose-6phosphate dehydrogenase. Cold Spring Harbor Symp. Quant. Biol. 29: 391 :

Laurent, G., Garcon, D., Marriq, C., Charrel, M., and Derrien, Y. (1965). Composition en amino acides et hydrolyse trypsique des anhydrases carboniques érythrocytaires humaines $\mathrm{A}\left(\mathrm{X}_{2}\right)$ et B $\left(\mathrm{X}_{1}\right)$. C. R. Acad. Sc. Paris 258: 6557.

Lowry, O. H., Rosebrough, N. L., Farr, A. L., and Randall, R. J. (1951). Protein measurement with the folin phenol reagent. J. Biol. Chem. 193: 265.

Maas, W. K., and Davis, B. D. (1962). Production of an altered pantothenate synthesizing enzyme by a temperature-sensitive mutant of Escherichia coli. Proc. Natl. Acad. Sci. (U.S.) $38: 785$. 
Malmström, B. G., Nyman, P. O., Strandberg, B., and Tilander, B. (1964). Studies on the active site of carbonic anhydrase. In Structure and Activity of Enzymes. Edited by T. W. Goodwin, J. I. Harris, and B. S. Hartley, Academic Press, New York, pp. 121-129.

Matsubara, H., and Smith, E. L. (1963). Human heart cytochrome c. J. Biol. Chem. $238: 2732$.

Micheli, A., and Buzzi, C. (1964). Étude électrophorétique et immuno-électrophorétique de l'anhydrase carbonique érythrocytaire humaine. Biochim. Biophys. Acta 89: 324.

Nakashima, T., Higa, H., Matsubara, H., Benson, A. M., and Yasunoba, K. T. (1966). The amino acid sequence of bovine heart cytochrome $c$.J. Biol. Chem. 241: 1166.

Nirenberg, M., Leder, P., Bernfield, M., Brimacombe, R., Trupin, J., Rottman, T., and O'Neal, C. (1965). RNA codewords and protein synthesis, VII. On the general nature of the RNA code. Proc. Natl. Acad. Sci. (U.S.) 53: 1161.

Niswander, J. D., Shreffler, D. C., and Neel, J. V. (1964). Genetic studies of quantitative variation in a component of human saliva. Ann. Hum. Genet., Lond. 27: 319.

Nyman, P. O. (1963). A spectrophotometric method for the assay of carbonic anhydrase activity. Acta Chemica Scand. 17: 429.

Nyman, P. O., and Lindskog, S. (1964). Amino acid composition of various forms of bovine and human erythrocyte carbonic anhydrase. Biochim. Biophys. Acta 85: 141-151.

Nyman, P. O., Strid, L., and Westermark, G. (1966). Carboxyl-terminal amino acid sequences of human and bovine erythrocyte carbonic anhydrase. Biochim. Biophys. Acta 122: 554.

Pocker, Y., and Stone, J. T. (1967). The catalytic versatility of erythrocyte carbonic anhydrase. III. Kinetic studies of the enzyme-catalyzed hydrolysis of $p$-nitrophenyl acetate. Biochem. 6: 668.

Rickli, E. E., Ghazanfar, S. A. S., Gibbons, B. H., and Edsall, J. T. (1964). Carbonic anhydrases from human erythrocytes. J. Biol. Chem. 239: 1065.

Shows, T. B., Tashian, R. E., Brewer, G. J., and Dern, R. J. (1964). Erythrocyte glucose-6-phosphate dehydrogenase in Caucasians: New inherited variant. Science 145: 1056.

Söll, D., Ohtsuka, E., Jones, D. S., Lohrmann, R., Hayatsu, H., Nishimura, S., and Kohrana, H. G. (1965). Studies on polynucleotides, XLIX. Stimulation of the binding of aminoacyl-sRNA's to ribosomes by ribotrinucleotides and a survey of codon assignments for 20 amino acids. Proc. Natl. Acad. Sci. (U.S.) 54: 1378.

Tashian, R. E. (unpublished).

Tashian, R. E. (1965). Genetic variation and evolution of the carboxylic esterases and carbonic anhydrases of primate erythrocytes. Amer. J. Hum. Genet. 17: 257.

Tashian, R. E., Douglas, D. P., and Yu, Y.-S. (1964). Esterase and hydrase activity of carbonic anhydrase I from primate erythrocytes. Biochem. Biophys. Res. Comm. 14: 256.

Tashian, R. E., Riggs, S. K., and Yu, Y.-S. L. (1966). Characterization of a mutant human erythrocyte carbonic anhydrase: carbonic anhydrase $\mathrm{Ic}_{\mathrm{G} u a m}$. Arch. Biochem. Biophys. 117: 320.

Tashian, R. E., and Shaw, M. W. (1962). Inheritance of an erythrocyte acetylesterase variant in man. Amer. J. Hum. Genet. 14: 295.

Tashian, R. E., Shreffler, D. C., and Shows, T. B. Genetic and phylogenetic variation in the different molecular forms of carbonic anhydrase. Ann. N.Y. Acad. Sci. (in press).

Watson-Williams, E. J., Beale, D., Irvine, D., and Lehmann, H. (1965). A new haemoglobin, D Ibadan ( $\beta-87$ Threonine $\rightarrow$ Lysine), producing no sickle-cell Haemoglobin D disease with Haemoglobin S. Nature 205: 1273.

Yanofsky, C. (1963). Amino acid replacements associated with mutation and recombination in the A gene and their relationship to in vitro coding data. Cold Spring Harbor Symp. Quant. Biol. 28: 581 . 